\title{
Field Library Services of the U.S. Department of Agriculture Library
}

Mrs. Buhler, chief, Division of Field Library Services, U.S. Department of Agriculture Library, gave this, the second of three papers, before the Agricultural Libraries Section of A.C.R.L., June 22, I942.

$\mathrm{M}^{\mathrm{x}}$

$Y$ PAPER will be confined to the operation of departmental branch libraries, although this is only a part of the department's interests in library service outside of Washington. The article on "Postwar Planning for Libraries in the Department of Agriculture" by Roy I. Kimmel and Ralph R. Shaw, the department librarian, which appeared in the A.L.A. Bulletin of February of this year, indicated four spheres of the department's interests in the subject. This was, I believe, the first time to appear in print a clear-cut tying-together of library service with the department's responsibility for the public aspect of agriculture in our economy and for the well-being of those engaged in agriculture as persons and as citizens.

The branch library idea-that is, the establishment of libraries in important centers of our department field staff with the purpose of serving all departmental workers of all bureaus-is less than a year old; however, field libraries within the department date as far back as 1907 , when the forest service was decentralized. Later the soil conservation service and other decentralized bureaus maintained small libraries or office collections for their own members in their regional offices. It is an interesting anomaly that although five out of every six departmental workers were stationed in the field and that there were more than forty bureau collections designated as libraries scattered around the country-some of them excellent in their narrow fields-still the large majority of our field workers were without library service from the department or its bureaus.

With one exception-the Little Rock Branch Library-all the branches were developed from such a collection, or a combination of such collections, and broadened in scope so as to include all phases of the agricultural programs in the regions. The purpose of branch libraries is to extend to field personnel of the department the same, of as nearly as possible the same, library service that the staff in Washington enjoys. The branch libraries are to serve as the bibliographical and reference centers for our staff in each region and are the regional clearing houses for the flow of information and other library functions. Whenever necessary subbranches are maintained in order to keep this flow of library material to workers in out-of-the-way places running as evenly and directly as possible.

The first step in planning our system of branch libraries was to survey and analyze 
each center in the country which serves as headquarters for more than five hundred department employees.

These three factors determined the type of library which should be established in each area:

(a) Subject fields represented by the research and action programs in the area. (This was arrived at by assembling project analyses of all departmental agencies operating in the area.)

(b) Type and amount of library service needed in order to ensure the success of these programs.

(c) Existing library facilities in the area and their availability to department workers.

\section{Preliminary Survey}

The preliminary survey was made in Washington with the aid of reports, correspondence, and talks with bureau chiefs. Each area was charted soon after the division of field library services began functioning, on July I of last year, by these more or less arm-chair methods, with a view to tackling the most pressing problems first. The preliminary surveys were followed by visits to areas under consideration and by further conferences and talks with workers on the ground.

The first branch library to be established was the Beltsville Research Center in Maryland, fifteen miles from Washington, which covers an area of more than twelve thousand acres. The center provides field and laboratory facilities for scientific workers representing nine bureaus of the department. Most of the research work formerly carried on in Washington and at Arlington Farm has been, or is in process of being, transferred to the center. The subject interests of the branch library, then, parallel those of the department library except that the economic and action programs are not represented.

The size of the book collection is purposely kept to minimum; the only criterion used in determining whether or not a book belongs at the branch library is the record of its actual use. The library's main value is in being a distribution center of the department library proper; its only claim or aim to comprehensiveness is in its sets of indexing and abstracting publications which cover every field of research being carried on at the center.

The library staff of seven is devoted to reference work, periodical scanning, and circulation, and to maintaining a steady flow of research materials to the staff. Book deliveries are made by motorcycle. Two regular trips are made daily over a nine-mile circuit, delivering to thirteen buildings. The largest of the buildings receive desk-to-desk service. A longer circuit of fifteen miles is made twice a week to cooperating agencies, among them the Patuxent Research Refuge of the Department of the Interior. Books requested from the department library in the morning, if not in use in the department, are received at the branch library the same day. So much for the only purely scientific research branch library in the system.

\section{Regional Libraries}

The other branches are regional libraries and serve both research and action agencies for ordinary and general library services, depending upon the department library in Washington for extended searches of literature, compilation of bibliographies, cataloging, and other technical aids. The nine regional branch libraries are located at these points: the Northeastern branch is at Upper Darby, Pa.; we have two South- 
ern branches, one at Little Rock, Ark., and one at Atlanta; the Great Plains branch is at Lincoln, Neb.; the Intermountain and Southwestern branches are at Albuquerque, N.M., and the Fort Worth-Dallas area; our West Coast branch is at San Francisco; and the Pacific Northwest region is served by our newlyestablished branch at Portland, Ore. We are now in process of organizing the branch to serve the Midwest in Milwaukee.

These regional library service areas coincide with those of other over-all departmental administrative agencies in the field.

In general, the nine regional branches follow similar patterns of organization and administration. Problems are, as a rule, common to all. The same basic agricultural reference books will be found in all, as well as the same general periodicals. An attempt is made to include in each branch library a few standard books on all phases of agriculture with emphasis, naturally, on the subjects of special interest in each region. For instance, seven of our branches would normally have one or two general books on 'cotton; our two Southern branches, at Little Rock and Atlanta, would have sizable collections on the subject. Each branch library as a matter of course is expected to be complete in its holdings of regional agricultural literature-complete in its records of all publications by department workers in the area, complete in its sets of agricultural college, experiment, and extension publications from the states which define the geographical limits of the region, and in its holdings of local farm journals.

\section{Composite Picture of Branch}

The services rendered in the regional branch libraries are, in general, comparable but in certain regions certain types of services are developed more highly than in others. The description which follows is a sort of composite picture of a branch library, typical of all but not a literal description of any one of the nine.

Our typical branch library is situated in a city with good library facilities. Satisfactory contacts have been made with neighboring libraries for interlibrary loans. The branch librarian has assumed the responsibility for agricultural literature pertaining to the region and receives in return from the other libraries help in general reference work and the like, thus making it unnecessary to acquire many books outside the field of agriculture and related subjects. The librarian is a college and library school graduate and has had experience in the department library before assuming the field job. She-I say she, because only two of the branch librarians are men-has two or three assistants and a full-time or part-time messenger. One of her assistants may be in charge of a subbranch, which may be a permanent arrangement made necessary by geography or transportation facilities or it may be a purely temporary expedient depending upon the present tire and gasoline shortage.

The staff served by our typical library is composed of five hundred or more agricultural workers in eight bureaus situated near the library and perhaps one thousand workers scattered in two hundred or so locations within the five states which define the geographical limits of the region, whom the librarian seldom sees and with whom she deals by mail-order methods.

\section{Book Stock}

The book stock, as mentioned before, has been developed from a small working collection of a single bureau and has been 
added to by analyzing the projects and working plans of all eight agencies in the region and representing these subject interests by the best books and periodicals in these fields. Project and division leaders work with the librarian in making sure that their fields are adequately represented, in adding their special knowledge in evaluating proposed book purchases.

After the orientation period, the branch librarian has the users and potential users charted, not only as to what an individual wants to read pertaining to his work but also has her home-made digest of work which has been done in the region, work in progress, and work contemplated, by geographical location and by divisions within the bureaus. In connection with this, three card records are kept. The first shows subject interests, with individuals' names added; the second is a list of individuals with notes on their interests (the same record, reversed); the third is a geographical index indicating service points with subject interests-that is, what agencies operate in Moccasin, Mont., for instance, and key men and important projects in each agency. From these records a regional map is prepared for the division of field library services and is used as a guide in keeping the field collections well-balanced and in keeping us alert in fulfilling our purpose of opening our total library resources to every member of the department, wherever his assignment might take him.

Not all librarians are invited to sit in on bureau staff meetings or interbureau conferences but those who are not invited still have means of keeping these records. Casual day-to-day discussions both in the library and in the offices with the men afford the same opportunity on a more informal basis. Part of the program of the regular regional library committee meetings is devoted to a discussion of developments and projected plans in which the library might participate. The library committees are composed of one member from each departmental agency operating in the region. Another means of analyzing the library needs in the region is directed particularly to the staff in the outlying areas. This is through a form request for information reading something like this:

-In planning library service for department employees in the region, we will find it helpful to know the subjects in which the various workers are interested.

For this reason, we would be very glad if you will indicate below, and return to us, the nature of the work or project in which you are now engaged and the subject interests involved or relating to the carrying out of your particular project or field of work.

We hope we may be able to lend any literature you may need in your work, and shall welcome your requests for the loan of library materials. Mail or telephone requests for library materials will be handled as promptly as possible-

Also, attached to the library Newsletters, which are issued regularly, is a blank form inviting requests for a specific title, requests by subject, or requests for a continuous type of service such as receiving periodicals regularly on circulation.

As the region's reference and bibliographical center, the branch library touches all phases of the department's work wherever books and library materials can further its research and action programs. The points of contact are many and varied. The range of reference questions and of all the special types of searching and bibliographical services required by the field men challenges the ingenuity and resourcefulness of the branch librarians. A few 
of the questions picked out from last month's report from the branch libraries will indicate the type of questions asked:

\section{Types of Questions}

From at least five of the branches came questions pertaining to all phases of guayule planting, culture, insect pests, harvesting, etc.

The same type of questions were asked for goldenrod, rabbit weed, Russian dandelion, Hevea, and other rubber-producing or potential rubber-producing plants.

Material on the history of land speculation during wartime.

Number of eggs to be sent to Great Britain in 1942.

When and where Secretary Wickard first said, "Food will win the war and write the peace."

Material and a reading list on charcoal and wood as gas-producers for motor equipment.

At least one question was directed to each branch library on the organization and management of farmer cooperatives. They included fur farms, vegetable and fruit canning and preserving, wood alcohol plants, egg and poultry plants.

The general run of reference questions fall into four major subject classifications.

Production, which includes soils, plants, and animals, and their protection.

Conservation and land use, with their many ramifications.

Marketing and distribution, which includes protection of markets, consumer protection, disposition of surpluses, nutrition, and the like.

Rural life, including the farm home, the rural community, and all phases of rural sociology.

These broad subject classifications may be subdivided into hundreds of more specific subjects, all impinging one upon the other, and most of the reference questions are directed toward small segments of these larger subjects.
In our monthly reports we divide reference questions and bibliographical work into these categories:

Type I. Request for a fact quickly found.

Type 2. Request taking search of thirty minutes.

Type 3. Request taking extended search.

Type 4. Request referred to another information source.

Type 5. Compilation of a list.

Type 6. A list already compiled by the library is sent.

Type 7. Request which does not fall into the above categories.

A list of all questions falling into Type 7 , together with notes on how they are handled, is sent to the division of field library services, as well as are all questions falling into any of the other categories if they are not satisfactorily and completely handled at the branch-that is, if additional searching by subject specialists in the department library is necessary.

\section{Traveling Library Service}

Our package or traveling library service, which has developed in certain of the regions, has been enthusiastically received. The library committees work closely with the librarian in deciding the type of contents in these packages which circulate on a regular schedule to four field offices, remaining in each office one month before being returned to the branch library for circulation count and for weeding out of pamphlets which have outlived their timeliness to be replaced and started on another routing schedule. Each package contains five or six books and about twenty-five pamphlets. The packages themselves are unpretentious. When our original supply of library bureau composition mailing cartons was exhausted, we then used laundry boxes, and at present, ordinary corrugated cartons. A letter, 
together with the routing schedule of the box and a few annotated reading lists with request blanks for loans, accompanies each package.

The material in the packages just mentioned is chosen with a particular group of workers in mind. Some are prepared specifically for soil conservation service workers, others for farm security workers, and so on. A different type of package is being worked out now to be sent to the state and county war boards. They contain, in the opinion of the department representatives on the regional war planning boards, the "must" reading of all local people working on the Food for Freedom program and on postwar planning plans, with the aim of building up a more constructive idea of the objectives and philosophies of the democracies in the war and postwar world, as well as a clearer picture of the department's responsibility in these programs.

The division of field library services administers the field libraries and it is the point of contact between them and the department library itself. All requests for loans, for reference work, and other requests for services are also received in this division, are distributed to the various other divisions for handling, and flow back to this division after completion. Thus, a single, daily letter to and from each branch library takes care of most of the usual business with our libraries except for loans and new books sent and other bulky packages.

\section{Technical Processes}

Cataloging and other technical operations necessary to the preparing of books for use is done centrally in the department library. Catalog and shelf cards are prepared and sent with the book, ready for filing in the branch library catalog. The routines for books for which Library of Congress cards are printed (except for department publications) are handled in much the same way as in other libraries which maintain branches. Subject headings for field books conform to those in use in the department library. If further analytics are necessary in the field libraries in order to bring out material of purely local interest, the additional added entries are made in the regional library. Library of Congress proof sheets for department publications are furnished to all branch libraries. Branch librarians indicate the sets of cards desired and return the proof sheets to us for ordering and preparation.

The department library stencils cards for all agricultural publications received for which L.C. printed cards are not available. Copies of the main cards of the stenciled series are sent weekly to the branches for similar checking. These also are returned to $W$ ashington with requests for the number of sets desired.

Cataloging, then, for the bulk of the material in the branch library is not a major problem. It is primarily a matter of making additional sets of catalog cards for their publications and filing the cards in the regional catalog.

A union catalog of all departmental holdings in the region is one of the most valuable features of the branch library. Not all the union catalogs can yet be said to be complete but they are all being kept up to date currently and older scattered holdings among the various bureaus are being consolidated into the one catalog as rapidly as time permits.

This outline of organization and function of the branch libraries of the department has been pure exposition. It has

(Continued on page 68) 
responsibility on the part of the instructor to not only inform himself as to the contents of the library but also to cooperate in interesting the student in its proper value.

The library, too, can do much to assist and encourage the student to make use of the books lining its shelves. The required reading will more or less take care of itself, but some effort must be made to interest the student in things other than facts and figures. He must be shown that books are not only medicine to be taken for one's intellectual health but are friends worth cultivating and respecting.

As has been stated, the library is more than just a dispenser of printed material ; it is a powerhouse and should endeavor by periodic displays and other pertinent programs to arouse the interest of student and instructor alike.

Thus far I have placed the whole burden on the shoulders of the library and instructor, apparently absolving the student from any responsibility whatever. The student, however, is not like a sponge ball bounced about between the walls of learning absorbing, or refusing to absorb, whatever he comes in contact with. No matter how great his opportunities, they are wasted until he applies himself and avails himself of them.

The student should learn to use his library as a place of mental recreation and stimulus as well as for study. Once the technicalities of the indexes, file boxes, and references are mastered he will find the library has a character all its own.

He should spend an hour or two whenever possible doing nothing but browsing. Handle the books, become familiar with their size and shape, color and design. Each book has a personality of its own, seldom revealed by its call number. There is a pleasant mustiness about an old book, a crisp vigor about a new book which can only be known through actually handling them.

As a student I would say, therefore, that the junior college library is important as a source of supplementary textbook reading, a convenient and congenial place for study and for acquiring a greater knowledge through the thoughts and lives of men of all ages.

\section{Field Library Services of the U.S. Department of Agriculture Library}

\section{(Continued from page 40)}

perhaps not communicated to you more than a factual statement concerning the groundwork which has been laid the past eleven months and has not indicated to you the vastly interesting nature of the job. As Gaus and Wolcott ${ }^{1}$ have pointed

\footnotetext{
1 Gaus, J. M., and Wolcott, L. O. Public Administration and the United States Department of Agriculture. Chicago, Public Administration Service, I 940 . $534 \mathrm{p}$.
}

out, except for an over-all picture, the work of the department should be viewed not from its Washington center but from studies from its regional centers. The really stimulating and interesting papers about our field work will be written by the field librarians themselves who will have firsthand stories to tell. 